Clare Hemmings ${ }^{1}$

'London School of Economics and Political Science, London, United Kingdom

\title{
A Feminist Politics of Ambivalence: Reading with Emma Goldman
}

\begin{abstract}
Feminist theory worldwide is confronting - perhaps as it always has done - a series of deep challenges. On the one hand, awareness of gender and sexual inequalities seems high; on the other, co-optation of feminism for nationalist or other right-wing agendas is rife. On the one hand, feminist social movements are in ascendancy, on the other there is a continued dominance of single issue feminism and a resistance to intersectional, non-binary interventions. If we add in the collapse of the Left in the face of radical movements such as those underpinning Brexit and Trump (and the frequent blaming of feminism for fragmentation of that Left) then it is hard to know what to argue, to whom, and for what ends. In the face of such claims it is tempting to respond with a dogmatic or singular feminism, or to insist that what we need is a shared, clear, certain platform. I want to argue instead - with Emma Goldman (anarchist activist who died in 1940) as my guide - that it can be politically productive to embrace and theorise uncertainty, or even ambivalence, about gender equality and feminism.
\end{abstract}

Keywords: Feminism; ambivalence; Emma Goldman

\section{Introducing Ambivalence}

This project centres late $19^{\text {th }}$ and early $20^{\text {th }}$ century anarchist activist Emma Goldman as the point of attachment through which I explore several related aspects of contemporary feminist and queer historiography and politics. I argue that the uncertainty that characterises feminist and queer understandings of gender, race, and sexuality in the present is easily obscured through propositions of certainty about precisely these central concerns. In imagining that we know how to ameliorate gendered, racial, and sexual inequalities, or indeed what gender, race, and sexuality are, it is easy to miss the profound ambivalence about these terms and the inequalities or pleasures that cluster around them (historically and contemporarily). That ambivalence is in fact fundamental to both the past and the present. It animates political struggles over and with precisely those objects we imagine we inherit as knowable, and it runs back and forth across time to challenge progress or loss narratives

\section{(c) (7)}

Esta obra está sob licença Creative Commons. 
about where we come from and what political terrain we occupy now. Attending to ambivalence as a continuous political and affective reality for those who want to intervene in gendered, raced, and sexual meanings and structures in order to ameliorate their harms shifts the nature of historical and contemporary inquiry. This approach refuses a political teleology that laments the loss of Left solidarity, for example, or one that celebrates an increasing integration of race within feminist or queer theory. It runs counter to a rights-based approach that characterises the long twentieth century as one of increased recognition (or a lament about lack of recognition, or misrecognition), focusing attention instead on what is lost through a politics of certainty. What is gained from embracing a politics of ambivalence is a view of the past and present that centres both psychic and social aspects of inequality, the tenacity of our attachments to the objects that poison our lives, to paraphrase Leticia SABSAY (2016) and an opportunity to engage in the struggle over what inequality is and how best to intervene to transform it. It tries to imagine inhabiting a reality as well as politics of ambivalence, and foregrounds the importance of affect as a guide to asking important political and theoretical questions. But if the past and present of feminist and queer politics are marked by ambivalence, then what tools do we need to take up in order to glimpse that past and make it fit for present purpose? How can political ambivalence be animated to ameliorate rather than increase inequality, and how will a critic or audience know the difference?

This project is thus not a great-person history with Goldman at its centre. It is not primarily an attempt to position Goldman as a lost foremother of a feminist or queer project that is necessarily the worse for ignoring her (although she most certainly did not like to be ignored). But neither is Goldman an accidental choice, of course. It is her own fervent ambivalence about issues I hold dear in my own present, her consistent attention to questions of difference, and her failure to resolve the problematics that govern those questions that have drawn me to Goldman. So too it is her presence as a powerful figure in my own life (much as for Wexler), coming in and out of it at different moments, that makes me want to engage her in a conversation, the direction of which I am not fully able to anticipate. It is my feeling for Goldman and my enjoyment of her person and polemic that have opened up a range of theoretical and political questions for me about ambivalence at a variety of levels. It is in and through my attachment to her that I have come to imagine the past and present differently and to (imperfectly) see that ambivalence might also be inhabited with "panache".

A friend gave me a picture of Emma Goldman when I was seventeen years old, and in it she is only a few years older than I was then. The picture shows her meeting the camera's gaze face on, chin up slightly, hair pulled back, an uncomfortable-looking dress covering her slight frame. At the time I knew nothing of the importance of Goldman's image as part of how people tried to make sense of her; I was simply captivated by the mismatch between "anarchist" and "young woman" that the picture represented. I bought Emma GOLDMAN's autobiography, Living My Life (1970 [1931a, 1931b]), and found out that this Jewish Russian woman had migrated to America when a teenager, moved to New York City as soon as she could escape her family (and early marriage) in upstate New York, and by her late twenties had become the "High Priestess of Anarchy". I was in awe of this young woman who had travelled across America lecturing on anarchist revolution, minority creativity, sexual politics, and state violence, and whose refusal to misrepresent herself or her cause meant repeated prison terms. I felt her loss when her lifelong friend and comrade, Alexander Berkman, was imprisoned for his failed attempt on the life of Henry Clay Frick, and her fear when she was blamed for radicalising Leon Czolgosz, President McKinley's assassin (GOLDMAN, 2003 [1901]). I entertained fantasies of refusing to recognise the authorities at the Church of England private school where I was a sixth-former, but knew I would not be able to sustain any such 
"revolution" beyond its initial frisson of transgression. Instead, I marvelled at Goldman's standoff with J. Edgar Hoover, broken only by her being stripped of citizenship and deported to a postrevolutionary Russia. I appreciated the prescience of her critiques of the new Russian state authority, its violence and exclusion, and her disappointment at its failed postrevolutionary project, as well as the International Left's myopia (GOLDMAN, 1925). In part, I relished this critique because it resonated with my own youthful 1980s, Thatcher-inspired anticommunism, in contrast to Alice WEXLER (1992), who is outraged by Goldman's perpetuation of the "'Bolshevik myth'” (p. 44), writing from her own location as a frustrated American leftist in the same time period.

Forced and chosen travels through Europe in the 1920s were by turns clear sources of frustration and pleasure for Goldman, as she struggled to find a place to belong: part of her remained forever attached to America, its newness perhaps mirroring her own youth and optimism while there. The difficulties that Goldman experienced travelling across borders and her frequent disappointments in comrades (that pepper her autobiography and letters) were ameliorated by moments of intimacy and solidarity. She married James Colton for papers, her complicated friendship with Berkman remained strong, and she continued to pursue lust and love despite recurrent heartbreak. For a seventeen-year-old who dreamed of similar (literary and intimate, if not political) comradeship, what was not to like in this tale of thwarted ambitions and heroism? I later read in letters of her frequent illness and loneliness, her misery after Berkman's death in the south of France (where she wrote her autobiography), and her doubts about the value of anarchist revolution. Despite viewing her as being on the wrong side of history and progress, l embraced what John CHALBERG suggests is her "American individualism" (2008 [1991]), agreeing with her sense that against the odds her life had indeed been "worth while" (GOLDMAN, 1991b [1933]). I too wanted a life filled with ups and down, a heroic life, and I sighed with satisfaction at Goldman's autobiographical conclusion that she had lived hers "in bitter sorrow and ecstatic joy, in black despair and fervent hope. I had drunk the cup to the last drop" (1931b, p. 993).

But what truly caught me in Goldman's life and work, and that pulled me into reading Anarchism and Other Essays (1910) from start to finish one wet weekend, was the particular combination of her sexual politics and her disidentification from contemporary feminism. In alignment with my right-wing That cherite commitments, I was also rather virulently antifeminist myself at the time of this encounter, taking enormous pleasure in scoffing at attempts to give women or girls what I saw as "special attention." I was a perfect audience for Goldman's scathing indictments of both bourgeois femininity and dusty, censorious feminism. Goldman reflected back to me my youthful interest in fashioning myself as an assertive subject, capable of anything, not to be cowed by norms as foolish as those of gender or sexuality.

When I was coming to the end of my last book some twenty-five years later, and was sifting through my mind for a new focus, Goldman kept coming back to me. I rummaged around to find that old image of her (that I had apparently never thrown away), and as I looked at it, I was captivated anew. We might say that I am now surely as invested in feminism as once I was hostile towards it. Yet that captivation echoes between these politically distinct selves to suggest something affectively common to both that has inaugurated this project. Both my younger and my older selves are suspicious of feminist projects that characterise women as in need of protection; both hold no truck with naturalised accounts of femininity or masculinity; both share an existentialist vision of a degendered human capacity that must surely lie at the heart of any real cultural and political transformation. My older self has come to align these critiques with both Left and feminist commitments, but I suspect that my younger self was more comfortable with the ambivalence of uncharted sexual and gendered territory. 
The Goldman archive is overflowing with ambivalence about gender and sexuality, in ways that may initially come as a surprise. After all, this is Emma Goldman, who is unequivocal about the central role that sexual politics and the gendered division of labour and value play in the perpetuation of capitalist and militarist interests. Goldman spent her life foregrounding the inequalities attending and reinforcing women's subordinate role and was still making arguments about the importance of women as revolutionaries in her late sixties, when she was active in supporting the anarchist movement in Spain (Martha ACKELSBERG, 2001 [1937]). Goldman insisted that women's position in the family was a fundamental feature of how capitalism worked (rather than its lamentable side effect), emphasising the importance of the exploitation of their reproductive labour, as well as the impact of this tyranny on women as individuals. She was an early advocate of women's birth control, for which she was imprisoned (GOLDMAN, 1991 a [1906]). Goldman (1911) railed against the ills of femininity that keep women locked into domestic servitude and was forthright on the centrality of women's emancipation to social and political transformation (GOLDMAN, 1991 a [1906]). It was, in fact, precisely because Goldman wanted to centre women's freedom as essential for revolution that she was so critical of suffrage and the limits of efforts to gain the franchise (GOLDMAN, 1917). For Goldman, only women's fullest liberty would do, and she understood state-oriented recognition politics such as the claiming of the vote as a waste of revolutionary energy. In this she was not alone, of course: women's sexual and political freedom was consistently contrasted with the red herring of feminism or equality in a range of international anarchist movements in Argentina and Chile, for example.

The feminist critical archive has sought to rescue Goldman from this "splitting" at the heart of her revolutionary project on women by declaring that she is in fact a feminist, despite her resistance to the name. Feminist writers consistently claim her as such on the basis of these radical views of women's emancipation and provide a series of caveats to reframe her antipathy to feminism as of her time and politics, rather than something to worry about too much in bringing her forward (Alix Kates SHULMAN, 2007 [1982]). Alternatively, feminist critics point to her own failed project of sexual freedom as a good example of all feminists' failure to achieve our ideals, citing her anxiety-producing level of devotion to male lovers (Lori Jo MARSO, 2003) and her lack of attention to divisions of domestic labour (Christine STANSELL, 2009 [2000], p. 258) as aspects of her (still feminist) complexity that we can usefully learn from. Goldman's rather frequent unpleasantness to women is harder to integrate into this claiming of her as a feminist, though. While most feminist thinking includes a critique of femininity and of (some) women in their representation and reproduction of the status quo, Goldman is understood to take her judgements too far in this respect. She can be vitriolic towards women (representing them as stupid, vicious, petty, and corrupt), and - probably more important - she clearly takes great pleasure in her characterisation of bourgeois women as arch consumers and of women in general as responsible for many of men's failings (GOLDMAN, 1931b, p. 556). It is Goldman's enthusiastic antipathy towards femininity that signals her ambivalence about women's capacity to change in the subjective archive, while in the critical archive, it is the faltering desire for Goldman to be a feminist and the difficulties of succeeding in that endeavour that are instructive. In wanting Goldman to be a feminist in order to claim her as valuable to a feminist project, I will be suggesting that contemporary feminist theory seeks to mask its own ambivalence about precisely these same - and unresolved - questions about femininity and feminism.

Goldman's ambivalence about femininity resonates with the feminist archive, but her ambivalence about race and racism is harder for the archive to negotiate. In relationship to race and racism, feminists have noted with some dismay that Goldman "'misses race"" (Kathy FERGUSON, 2011, p. 217-229), and to some extent they respond in a similar vein, 
ignoring the dilemmas that run through the subjective archive, claiming her instead as an intersectional heroine before her time. This is commonly achieved by focusing on her internationalism, Jewish identity, and community attachments (Marilyn REIZENBAUM, 2005; WEXLER, 1992) and her focus on migration and antinationalism (Kathleen KENNEDY, 1999), which certainly were strong features of Goldman's politics. Yet in the process of this reclamation effort, Goldman's reflections on race and racism, her (not always consistent) attempts to integrate class and race analysis, her comparisons between anti-Semitic and antiblack violence in America (GOLDMAN, 1910, 69-78; GOLDMAN, 1927, in Richard DRINNON; Anna Maria DRINNON, 1975, p. 196), as well as her development of a "post-racial" model of kinship (GOLDMAN between 1927 and 1930), receive less attention than they deserve. In wanting Goldman to be attentive to race and racism in ways that are familiar to contemporary feminist theorising, the critical archive deflects attention from the ways in which Goldman negotiates these questions in conflicting and conflicted ways. In the process, that critical archive also protects a contemporary fantasy that questions of race and racism can be straightforwardly integrated as part of an intersectional analysis. In the attempt to present contemporary feminist theory both as attentive to race and as knowing what that attention should involve, the ongoing ambivalence about the relationship between race, class, gender, and sexuality in the theoretical archive is minimised if not directly repressed. As with attention to ambivalence about femininity and feminism, however, a more open approach to "what race is and means" might enable a politics more attuned to the continued uncertainty about the relationship between race and class, and point to ways in which a fuller analysis of sexual freedom challenges the nationalist and racialised understanding of "the family."

To give a little more detail of these threads here, and to flesh out our initial encounter with Goldman, we should note that Goldman (1908; 1915) was a practical and intuitive internationalist. She herself migrated or was exiled numerous times during her lifetime, and she had a trenchant critique of the relationship between nationalism, militarism, and capitalism, particularly insofar as these limited the possibilities for women to live full lives. She was thus a supporter of the Indian anticolonial movement (James Daniel ELAM, 2013) and the Mexican Revolution (Candace FALK, 2012) and worked towards "solidarity with anticolonial struggles in Africa and the Philippines" (Hilton BERTALEN, 2011, p. 225). Goldman was of course one of those anarchist migrants who became politicised after her move from Russia to the United States, and who was first educated in and then exiled to Europe (GOLDMAN, 1931a, 1931b). She fought to make anarchism a broader movement in the United States once she had converted to anarchism by lecturing in English rather than Yiddish or German as was the convention among New York anarchists in the 1880s and 1890s (STANSELL, 2009 [2000]). She wrote to comrades and intimates all over the world no matter where she was living, and she participated in that vast network of transnational anarchist publication and translation that typified its vibrancy. As Falk thus notes, for Goldman "the crossing of national boundaries, so integral to Goldman's political vision was also critical to the longterm impact of her political work" (FALK, 2005, p. 64). Goldman's border crossings and lack of belonging underwrite her challenges to patriotism and capitalism, as well as the gendered and sexual norms that secure them, and these skeins of her life resonate well with a feminist critical and theoretical archive that foregrounds a transnational feminist politics attentive to contemporary geopolitical complexity.

It is certainly true that Goldman, like many other European, Latin American, and American anarchists, was less clear on how to negotiate race politics, particularly while in the United States. For Ferguson, Goldman's political commitments meant that "she was confident that class would always trump race in the production of social inequality" (FERGUSON, 2011, p. 220), and for Falk, while Goldman had a clear analysis of lynching as "the most graphic and 
egregious expression of racist terrorism in the country," she did not theorise that horror as "the focus of her general critique" of state aggression (FALK, 2012, p. 12-33). Yet what interests me about this critical engagement is that this focus in Goldman is framed as self-evidently problematic, as clearly erroneous if not privileging race and racism. As a result of this critical "embarrassment" about how she "misses" race, a range of ways in which Goldman does explore how racism functions as a form of oppression are easily missed in turn. In wanting Goldman's attention to race to be familiar and privileged, the attention that she pays to lynching and her analysis of the concept of "slavery" are glossed over. And in turning to her critiques of nationalism, or the mobilisation of Jewish identity as an alternative, in framing her as an intersectional heroine ahead of her time (despite this inattention to race and racism), the very ways in which these approaches combine to provide a somewhat unexpected account of race and sexual freedom, or analysis of the relationship between anti-Semitic and anti-black violence, are also too easily overlooked. And in particular her critique of race as embedded in 'the family', such that the expansion of kinship through sexual freedom is also a prefiguration of an anti- or post-race cosmopolitanism central to anarchist utopia...

And what of sexual freedom? Surely Goldman could not be thought of as ambivalent in this respect... Goldman was among those early twentieth-century anarchists and socialists who understood sexual expression to be a "basic human right, a legitimate goal of the class struggle". Indeed, Goldman's centring of sexual freedom at the heart of her revolutionary vision forms part of a long tradition of engagement with sexual politics on the Left, one that endeavours to make sense of how productive and reproductive labour come together and to identify the difference between sexual freedom and capitalist co-optation at both practical and theoretical levels. Goldman theorises the sexual division of labour not simply as a prior condition for production and thus capitalist exploitation but as labour (alienated and exploited, as is other labour in capitalism), and thus an integral part of economic production. Through this analysis, Goldman links birth control issues, prostitution, and wholesale destruction of the poor in wartime and develops her strong arguments for love as the site of reclaimed value, creativity, and progressive possibility when returned into the hands of its workers: women. Goldman not only theorised sexual freedom, of course, but also practiced it through her life, refusing to be domestically tied to men or children, and struggling with the contradictions between feelings and politics that structure her bravery in this respect (GOLDMAN, 1931a, 1931b).

The feminist critical archive on Goldman's understanding of sexual freedom is of course seduced by that centring of sexual politics as both means and end of utopia, and by Goldman's linking of nationalism, militarism, and control of women's bodies. Her support for and theorisation of prostitution as an effect of capitalism, migration, and repressed sex drives have pleased queer theorists too, as has her sometimes contradictory support for homosexual liberty. But so, too, that archive finds limits to this privileging of sexual freedom, representing it as too vague, on the one hand, and excessively focused on love for men, on the other (MARSO, 2003, p. 306; STANSELL, 2000, p. 142). Bonnie HAALAND (1993) perhaps goes furthest in this line of thinking, framing Goldman as a heterosexual essentialist because of her support for sexological and psychoanalytic understandings of sexuality, as well as her uncertain relationship to homosexuality. But a range of different thinkers celebrate Goldman's bold relationship to sexual freedom in her life and work, while also remaining dubious about her claiming of sexuality as the core of human nature, whatever its object choice (Janet E. DAY, 2007, p. 110; Linda L. LUMSDEN, 2007, p. 45). It is important, I think, to consider the ways in which Goldman is interrogating the question of sexuality's relationship to capitalism and freedom at a point when sexuality as an identity is in the process of being articulated. Goldman is forging her own theory of sexual freedom as a difficult and contested rather than 
self-evident position of critique or transformation. In addition, Goldman's complex engagement with sexual politics (in theory and in practice) poses an important challenge to assumptions about the nature of sexual identity and freedom in the present. Goldman's support for birth control positions her in an ambivalent relationship to eugenics in her own time, and her claiming of "nature" as central to sexual freedom returns us to concerns about racialisation, insofar as she links this to primitive drives. But so, too, Goldman's ambivalence about homosexuality (her own as well as other people's) moves us firmly away from both single-issue and identity politics that govern and limit contemporary understandings of sexual rights. As in my readings of subjective, critical, and theoretical archival ambivalence concerning femininity and feminism, and race and internationalism, my interest here is in the consequences of taking Goldman's sexual ambivalence seriously as politically and historiographically significant for queer feminist studies today.

\section{Ambivalent Tactics}

The question of methodology is particularly central to my engagement with Goldman's understanding of sexual freedom. On the one hand, I am advocating an approach that reads for ambivalence across the Goldman archive; on the other, I am aware that in relationship to sexual freedom in particular, that same question of ambivalence can easily be obscured. The clear emergence of sexual identities through the twentieth century and the contemporary foregrounding of rights over freedoms in political contexts actively work against reading for ambivalence in both dominant and resistant modes. Homonationalism, for example, has shown us the ease with which identities can be taken up as part of border patrolling, but also how easy it is to roll back basic rights when no longer popularly supported (as in the case with LGBT and abortion rights across the world). The task is thus a politically motivated one that starts from an interest in what is left out of the frame, and how to think from the (nonidentitarian) margins in the spirit of Goldman's own contradictory, anarchist interventions around sexual freedom. These questions of how to explore ambivalence when its traces have effectively been erased have been central to my inquiry, and I think are key to a progressive methodology for political sustainability in universal vein.

At the level of analysis, I foreground tensions in Goldman's thinking and responses, rather than seeking to resolve them. I believe that it is more helpful to contemporary queer feminist theory to bring forward Goldman's ambivalence than to import the aspects of thinking and living that most clearly fit with the (often misplaced) certainties of the present. A sustained focus on ambivalence helps us to engage past politics and theory as complex or contradictory, and to foreground the importance of current complexity, despite our desire to have resolved both past and present paradoxes. For in relationship to the key areas raised thus far, feminist theory most certainly has not resolved the question of judgement of femininity or the relationship between feminism and its conflicted subjects; the relationship between race, migration, class, and gender in the present is less easily articulated than current intersectional approaches might perhaps have us believe; and yet faith in human nature remains central to political hope. I want to engage Goldman in order to disrupt the relationship between past and present, to challenge a critical certainty that there is a singular story that we can tell about how we got to where we (think we) are now. I want to read with and in tension with Goldman's struggles to allow her to shine, and I want to demonstrate that how we approach the past and the throng that peoples it - raises a host of ethical and methodological questions about knowledge and politics.

The role of the critic is of course key here. I ask: What slips outside of my grasp, or is easily framed as someone else's bad habit? And yet, what is it that I might want to push 
away, but which continues to insist, keeps on interrupting the neat narratives of self, theory, and politics I have a vested interest in? In methodological terms, it is my own affective response to the archive that has opened up for me what I might know but (tend to) deny in relation to Goldman. I laughed uproariously at Goldman's viciousness to women when I first encountered it in her writing, sharing nasty laughter at women's manipulability and culpability for their own oppression. I have come to think of that pleasure as a way of letting my partner in crime carry the burden of our shared judgement of femininity; it lets me off the hook even as it binds me to Goldman. My initial response to Goldman's understanding of race and racism in her work was also highly affective. I shared the critical disappointment at her lack of sustained theorising of race politics and found a firmer footing in reframing her as a prophetic intersectional thinker instead. Yet something niggled at me, made me ashamed at my own displacement of race politics that seemed to mirror hers, even as I sought to distance myself from her in this regard. And finally, I wrestled for some time with my bodily glow at Goldman's sexual politics, her insistence on human capacity as generous rather than mean-spirited, trying to control that common joy by filtering her through a more sophisticated contemporary critical sieve. In so doing, I missed for a long time the important temporality of Goldman's belief in human nature, a future orientation I was only able to glimpse when I gave in to that glow. Much as one might apologise for a well-meaning but embarrassing relative in ways one later feels as a reciprocal humiliation, my own attempts to clean up Goldman could not be sustained: she kept jabbing at my ribs and stomach and in each case brought me back to her ambivalence as considerably more engaging than my own superficial certainties.

Tempting though it surely is, then, my concern in this project is less with a search for lost sources and more with how we might read these archival gaps and half-grasped traces creatively. The shift is slight, but important, I think. It frames the ambivalent histories we inherit as ones that were always likely to have been lost. My interest in an imaginative archive that seeks to tell the unsayable and imagine what cannot be retrieved leans heavily on a history of postcolonial theory and fiction. Writers in this tradition insist that stories can and must be retold from the position of these gaps and fissures, but not in order to mend or simply include. Most famously, Jean RHYS (1966) in Wide Sargasso Sea retells Jane Eyre from the standpoint of the "madwoman in the attic," and J. M. COETZEE (1986) reimagines Daniel Defoe's Robinson Crusoe from the perspective of Susan Barton, who joins Crusoe and the voiceless Friday on the infamous desert island, and whose experiences are distorted or erased by Defoe himself. More recently, Joan ANIM-ADDO (2008) rewrites Aphra Behn's tale of Oroonoko from the point of view of his otherwise untraceable lover. These writers eschew a search for innocent origins or even reparation; these are renditions of the violence of dominant narratives that leave space only for confusion or howls that fill the night air. And their protagonists have no time for identity or futurity. Theirs is a struggle to hold on, to reflect, and to survive. And while that struggle is always lost - both for them and for posterity - the ripples it makes continue to register at the level of possibility, if not reality. Saidiya HARTMAN (2002), for example, starts from her sense of loss at the lack of stories of resistance to slavery in the archives. Surprised - and a little irritated by her own surprise - at the archival reflection of a dominant order (since resistance was routinely met with deathly obliteration), Hartman refuses to deny that historical violence, or accept what she encounters as the whole story. Instead, she embarks on a historical journey that begins from her desire for other traces of meaning beyond the deafening archival silence: if she wants evidence of solidarity in the face of annihilation, then she will have to imagine it and to embrace that which can't be verified.

My own aims in occupying the position of the imaginative historian are similar. I start from the letters that Goldman received from fellow anarchist activist and labour union organizer Almeda Sperry during 1912 and 1913. Sperry wrote a sequence of more than sixty seductive 
letters to Goldman, in which she depicts her frustration with small-town life and politics, her struggles with her husband, Fred, and her paid work for sex, as well as her desire for Goldman (which was temporarily reciprocated). There are no letters from Goldman to Sperry in the archive, and while I can entertain fantasies of their discovery in the attic of a distant relative of Sperry's, their loss is of course indicative. But as I read Sperry's letters to Goldman, I piece together their likely correspondence and enter a conversation between the two of them that reflects my own yearning for the letters that we do not have. In a fictional and political archival experiment, then, I write Goldman's letters to Sperry, using that reading dynamic as a springboard for imagining a past we do not have evidence of. I start from that yearning for those letters, both as a way of correcting assumptions about Goldman's heterosexuality - the critical archive tends to read our lack of evidence as her lack of desire - and as a way of imagining her pleasure and distance in relation to Sperry as filled with ambivalence. I start from the tension between wanting those letters and the knowledge that they not only have been lost, but were always likely to have been lost.

The letters I write back to Sperry seek to represent both aspects of her sexual politics that are part of the subjective archive, and aspects that elude us. I pore over Sperry's missives, taking in her frustration that Goldman has not written in ages, and her relief when she has received a letter. I can see that the letters were there, that Sperry received them, but only faint clues emerge as to what they might have contained: declarations of love and impatience; political diatribes; shared reading and frustration. I am interested both in the complexities of her own desire as we encounter it and in the parts that cannot so easily be confronted: her disgust as well as her pleasure, her fear as well as fierce courage and pride. The history I imagine is not one with identity at its heart but one that queers both the Goldman archive and the critical archive that longs for a safe and knowable history (or present). I write back to Sperry the letters I imagine Goldman writing when I read the ones we have, and in so doing I foreground both our collective failure to find them and the importance of still imagining them there. I am not prepared to read Goldman only through the traces that remain; instead, I want to bring to life a sexual history in which her own ambivalence, same-sex passion and disgust, fear and bravery must have crafted the words she wrapped around Sperry's heart. I write Goldman's letters back to Sperry as a kind of memory work that focuses on my own yearning for a stronger trace of her appetite and anger, and that I know I will not find except imaginatively.

I do not want to clean Goldman up, or reject her for her contradictions. I want to think with and through Goldman towards an ethics of representation and political ambivalence that starts from my own yearning for something that "cannot be verified" and from my gut feeling Goldman would have been tickled pink by my presumption.

\section{References}

ACKELSBERG, Martha. Free Women of Spain: Anarchism and the Struggle for the Emancipation of Women. Edinburgh: AK Press, 2001 [1937].

ANIM-ADDO, Joan. Imoinda: Or She Who Will Lose Her Name - A Play for Twelve Voices in Three Acts. London: Mango Press, 2008.

BERTALEN, Hilton. "When Theories Meet: Emma Goldman and 'Post-anarchism'”. In: ROUSELLE, Duane; EVREN, Sureyyya (Ed.). Post-anarchism: A Reader. London: Pluto Press, 2011 . p. 208-230.

CHALBERG, John C. Emma Goldman: American Individualist. New York: Pearson Longman, 2008 [1991].

COETZEE, John M. Foe. London: Secker and Warburg, 1986. 
DAY, Janet E. "The 'Individual' in Goldman's Anarchist Theory". In: WEISS, Penny A.; KENSINGER, Loretta (Ed.). Feminist Interpretations of Emma Goldman. University Park: Penn State University Press, 2007. p. 109-136.

DRINNON, Richard; DRINNON, Anna Maria (Ed.). Nowhere at Home: Letters from Exile of Emma Goldman and Alexander Berkman. New York: Schocken Books, 1975.

ELAM, James Daniel. "The 'Arch Priestess of Anarchy' Visits Lahore: Violence, Love, and the Worldliness of Revolutionary Texts". Postcolonial Studies, v. 16, n. 2, p. 140-154, 2013.

FALK, Candace (Ed.). Emma Goldman: A Documentary History of the American Years. v. 2, Making Speech Free 1902-1909. Berkeley: University of California Press, 2005.

"Into the Spotlight: An Introductory Essay". In: FALK, Candace (Ed.). Emma Goldman: A Documentary History of the American Years. Light and Shadows, 1910-1916, v. 3. Stanford: Stanford University Press, 2012. p. 1-171.

FERGUSON, Kathy. Emma Goldman: Political Thinking in the Streets. Lanham: Rowmanand Littlefield, 2011.

GOLDMAN, Emma. "Emma Goldman Defines Her Position". In: GOLDMAN, Emma. Made for America, 1890-1901. p. 478-480. Originally published in "Letter" to Lucifer", The Lightbearer, New York, November 11, 2003 [1901].

. "The Tragedy of Women's Emancipation." Mother Earth 1, n. 1, p. 9-18, March 1991a.

In: Emma Goldman Papers, reel 47, 1906.

Patriotism: A Menace to Liberty. New York: Mother Earth Publishing Association. In: Emma Goldman Papers, reel 47. 1908.

. Anarchism and Other Essays. New York: Mother Earth Publishing Association, 1910. . Marriage and Love. New York: Mother Earth Publishing Association, 191 1. In: Emma Goldman Papers, reel 47, 1911. "The Woman Suffrage Chameleon". Mother Earth, v. XII, n. 3, p. 78-81, May, 1917. . My Disillusionment in Russia. London: C. W. Daniel Company, 1925. Living My Life: Volume One. New York: Dover, 1970 [1931 a].

. Living My Life: Volume Two. New York: Dover, 1970 [1931b].

"Has My Life Been Worth While?". [Daily] Express, January 30. In: Emma Goldman Papers, reel 52, 1991b [1933].

HAALAND, Bonnie. Emma Goldman: Sexuality and the Impurity of the State. Montreal: Black Rose Books, 1993.

HARTMAN, Saidiya. "The Time of Slavery". The South Atlantic Quarterly, v. 101, n. 4, 2002, p. 757-777.

KENNEDY, Kathleen. "Liberty with Strings: The Case of Emma Goldman”. In: TOWNSEND, Kathleen K.; KENNEDY, Kathleen. Disloyal Mothers and Scurrilous Citizens: Women and Subversion during World War I. Bloomington: Indiana University Press, 1999. p. 39-53.

LUMSDEN, Linda L. "Anarchy Meets Feminism: A Gender Analysis of Emma Goldman's Mother Earth 1906-1917." American Journalism, v. 24, n. 3, 2007, p. 31- 54.

MARSO, Lori Jo. "A Feminist Search for Love: Emma Goldman on the Politics of Marriage, Love, Sexuality and the Feminine". Feminist Theory, v. 4, n. 3, p. 305-320, 2003.

REIZENBAUM, Marilyn. "Yiddish Modernisms: Red Emma Goldman". Modern Fiction Studies, v. 51, n. 2, p. 456-481, 2005.

RHYS, Jean. Wide Sargasso Sea. London: Andr. Deutsch, 1966.

SABSAY, Leticia. The Political Imaginary of Sexual Freedom: Subjectivity and Power in the New Sexual Democratic Turn. London: Palgrave Macmillan, 2016.

SHULMAN, Alix Kates. "Dancing in the Revolution: Emma Goldman'sFeminism". In: WEISS, Penny A.; KENSINGER, Loretta (Ed.). Feminist Interpretations of Emma Goldman. University Park: Penn State University Press, 2007 [1982]. p. 241-253.

10 Revista Estudos Feministas, Florianópolis, 26(3): e58564 
STANSELL, Christine (Ed.). American Moderns: Bohemian New York and the Creation of a New Century. Princeton: Princeton University Press, 2009 [2000].

WEXLER, Alice. "The Anxiety of Biography". In: ALPERN, Sara; ANTLER, Joyce; PERRY, Elisabeth Israels; SCOBIE, Ingrid Winter (Ed.). The Challenge of Feminist Biography: Writing the Lives of Modern American Women. Chicago: University of Illinois Press, 1992. p. 34-50.

[Received on $08 / 08 / 2018$ and accepted on 22/08/2018]

\section{Uma política feminista da ambivalência: lendo com Emma Goldman}

Resumo: A teoria feminista confronta mundialmente no presente momento - talvez como sempre tenha feito - uma série de profundos desafios. Por um lado, a consciência de desigualdades sexuais e de gênero parece alta; por outro, a cooptação do feminismo por agendas nacionalistas ou de extrema direita é frequente. Por um lado, aumentam os movimentos sociais feministas, e por outro há uma continuada supremacia do feminismo hegemônico e uma resistência a intervenções interseccionais não binárias. Se adicionarmos o colapso da esquerda face aos movimentos radicais como os que embasaram o Brexite Trump le a frequente acusação ao feminismo de ter fragmentado a esquerda) fica difícil saber o que argumentar, com quem e para quê. Diante desse quadro, fica-se tentada a responder com um feminismo dogmático ou singular, ou insistir na necessidade de uma plataforma compartilhada, clara e precisa. Quero argumentar, no entanto, - com Emma Goldman (ativista anarquista que morreu em 1940) como guia - que pode ser politicamente produtivo abraçar e teorizar a incerteza, e mesmo a ambivalência, com relação à igualdade de gênero e ao feminismo.

Palavras-chave: Feminismo; ambivalência; Emma Goldman.

Clare Hemmings (c.hemmings@lse.ac.uk) is Full Professor of the Gender Studies Department of the London School of Economics and Political Science. Her main research interests as feminist theory and studies on sexuality. From the publication of Why Stories Matter: The Political Gramma rof Feminist Theory (Duke University Press, 2011) to her most recent Considering Emma Goldman: Feminist Political Ambivalence \& the Imaginative Archive (Duke University Press, 2018), her major interests has been to investigate how feminist narratives contribute to non-essentialist and intersectional politics. 